\title{
TREATMENT OF GERM CELL TESTICULAR CANCER
}

\author{
Ana Koši Kunac, Milena Gnjidić, Zrna Antunac Golubić and Marija Gamulin \\ Zagreb University Hospital Centre, Department of Oncology, Division of Medical Oncology, \\ Unit of Uro-oncology, Referral Center for Treatment of Germ Cell Tumors \\ and Extragonadal Germ Cell Tumors of the Ministry of Health of the Republic of Croatia, Zagreb, Croatia
}

\begin{abstract}
SUMMARY - Germ-cell testicular cancer (GCTC) is a malignant neoplasm derived from the primordial germ cell. Although it accounts for approximately $1 \%$ of all malignancies in men, it is the most common cancer of younger male population, with the highest incidence between ages 15 and 35 . Testicular cancer incidence rate has risen globally over the past several decades, with the average increase in the incidence of testicular cancer in Croatia of 7\% per annum from the year 1983 to 2007. Two main groups are seminomas and non-seminomas, each accounting for 50\% of cases, and they differ in treatment modalities and response to therapy. Despite increase in the incidence rate, a promising circumstance is that GCTC has become a model of curable cancer. Because of advances in diagnostic procedures, sophisticated radiation techniques and especially the introduction of cisplatin based chemotherapy protocols together with advanced postchemotherapy surgical techniques, curability is expected in about $95 \%$ of all patients diagnosed with testicular cancer and over $70 \%$ of patients with advanced disease. In this review, we will focus on treatment strategies of primary GCTC.
\end{abstract}

Key words: Germ-cell cancer; Seminoma; Non-seminoma; Chemotherapy

\section{Introduction}

Germ-cell testicular cancer (GCTC) is a malignant neoplasm derived from the primordial germ cell. It normally occurs inside the testicles, but in cases of errors during embryonal development (5 percent of cases) it can arise in extragonadal locations (cerebellum, pineal gland, mediastinum, retroperitoneum). Although it accounts for approximately $1 \%$ of all malignancies in men, it is the most common cancer of younger male population, with the highest incidence between ages 15 and $35^{1,2}$. According to the latest data from the Croatian National Cancer Registry from 2014 , the incidence rate of all newly diagnosed patients with testicular cancer was $9.4 / 100000$, with the highest incidence rate of 28/100 000 between the ages 30 and 34 years $^{3}$. Testicular cancer incidence rate has

Correspondence to: Ana Koši Kunac, MD, Zagreb University Hospital Centre, Department of Oncology, Kišpatićeva 12, 10000 Zagreb

E-mail: anakosi@gmail.com

Received November 15, 2018, accepted January 7, 2019 risen globally over the past several decades, with average increase in the incidence of testicular cancer in Croatia of 7\% per annum from the year 1983 to 2007, with the projected increase in the incidence of testicular cancer of $72 \%$ by the year $2025^{4,5}$.

The common influence of genetic predisposition and environmental factors plays a role in testicular cancer incidence rate upsurge. Contrary to current beliefs, there is no correlation between testicular cancer and testicular trauma, motorcycle driving, horseback riding, vasectomy, viral infections, or longer exposure to high temperatures ${ }^{2}$. The best characterized risk factor is cryptorchidism, where the earlier time of orchiopexy reduces the risk of testicular cancer. Another known risk factor is positive family history with 8-10 fold increased risk in siblings of a person with testicular cancer and 4-6 fold in the son of a person with testicular cancer. In some other genetic disorders such as Klinefelter's syndrome, Down's syndrome and testicular dysgenesis syndrome, a higher rate of testicular cancer incidence is seen, as it is also seen in men diagnosed earlier with primary testicular cancer ${ }^{1}$. 
It is thought that tumorigenesis starts in primordial germ cell that fails to differentiate into spermatogonia. This malignant transformation happens in utero and results in a precursor lesion known as intratubular germ-cell neoplasia (ITGCN) ${ }^{6}$. Until the onset of testicular hormone changes during puberty, ITGCN does not have invasive potential. After hormonal and other yet unknown influences, ITGCN has the ability to develop into germinal and somatic malignant tissues. Seminoma is one of the main histologic types of GCTC, which is derived from transformed germ cell that resembles gonocyte, but is blocked in differentiation. Another main type of GCTC is non-seminoma, which often consists of several other histologic subtypes. The most undifferentiated type is embryonal carcinoma, which can go in extraembryonal differentiation predisposing to choriocarcinoma and yolk sac tumor, or it can go in somatic differentiation predisposing to teratoma $\mathrm{a}^{7,8}$. These two main groups, seminomas and non-seminomas, account for $50 \%$ of cases each, and differ in treatment modalities and response to therapy.

Despite increase in the incidence rate, a promising circumstance is that GCTC has become a model of curable cancer. Because of advances in diagnostic procedures, sophisticated radiation techniques, and especially the introduction of cisplatin based chemotherapy protocols together with advanced postchemotherapy surgical techniques, curability is expected in about $95 \%$ of all patients diagnosed with testicular cancer and over $70 \%$ of patients with advanced disease ${ }^{9,10}$.

\section{Diagnosis and Staging}

Palpated scrotal mass is evaluated with scrotal ultrasonography, which should determine the etiology. Testicular cancer is described as a solid, hypoechoic mass. Testicular biopsy should never be performed because of the tumor seeding risk. Measurement of beta subunit of human chorionic gonadotropin (bHCG), alpha fetoprotein (AFP) and lactate dehydrogenase (LDH) should help confirm the diagnosis. Raised $\mathrm{LDH}$ is not specific for germ-cell tumor; rather it is an indicator of disease volume ${ }^{11}$. Radical inguinal orchiectomy with detailed histopathologic report on tumor histology, size, and presence or absence of lymphovascular invasion is a diagnostic and therapeutic approach. Disease staging should be done with computed to- mography imaging of the chest, abdomen and pelvis, and measurement of postorchiectomy tumor markers (bHCG, AFP and LDH). Testicular cancer is categorized in three stages according to the American Joint Committee on Cancer, $8^{\text {th }}$ edition $(\mathrm{AJCC})^{12}$.

In this review, we will focus on treatment strategies for primary GCTC.

\section{Treatment}

\section{Seminoma stage I}

Stage I is defined as a tumor limited to the testis, without retroperitoneal lymph node involvement or visceral metastases and with normal postorchiectomy serum tumor markers at primary diagnosis. About $80 \%$ of patients are diagnosed at this stage, and the majority are cured with orchiectomy alone. Following orchiectomy, the 5-year relapse rates are 15\%-20\%. Relapses are most likely to occur within the first two years after orchidectomy and relapse rate declines beyond the fifth year ${ }^{13}$. Following orchiectomy, there are 3 options recommended for the management of stage I seminoma, as follows: active surveillance, adjuvant treatment with radiotherapy to para-aortic lymph nodes, or adjuvant 1-2 cycles of chemotherapy with carboplatin, dosed at the area under the curve (AUC) of $7^{12}$. The most encouraging fact is that in case of relapse, the overall 5-year disease specific survival is $99 \%$, independent of the 3 management options mentioned above $^{1}$.

Many groups have tried to investigate the risk factors in predicting relapse to ease identification of patients that should be allocated to active surveillance and those that should receive adjuvant treatment. Primary tumor size greater than $4 \mathrm{~cm}$ and rete testis invasion have shown promising results as risk factors. In subsequent studies, there was insufficient evidence to support these findings, so the routine use of these predictive factors is not currently recommended ${ }^{9}$. On active surveillance, there is a relapse rate of $20 \%{ }^{12}$. This means that $80 \%$ of patients on active surveillance will be cured without any further treatment. With adjuvant radiotherapy or chemotherapy, they would be unnecessarily exposed to the potential acute and long term toxicities without improvement in overall survival. The goal of active surveillance is to spare $80 \%$ of patients of toxic treatments and in case of relapse, they can still be 
cured in $99 \%$ of cases 9 . According to these data, active surveillance is the preferred option in relevant guidelines and in our Referral Center for Treatment of Germ Cell Tumors and Extragonadal Germ Cell Tumors in Croatia. The potential disadvantages of active surveillance are the lack of patient compliance and exposure to imaging related radiation.

Alternatives to active surveillance are either adjuvant radiotherapy or chemotherapy. In both options, the relapse rate after treatment is about $4 \%{ }^{1}$. Although the dose and field of radiation was reduced over the past 20 years to $20 \mathrm{~Gy}$ administered in 10 daily 2.0 fractions to para-aortic and/or ipsilateral iliac lymph nodes, adjuvant radiotherapy in stage I seminoma has been abandoned in many major medical centers because of the long term risk of secondary malignancies and cardiovascular toxicity ${ }^{1,2}$. Adjuvant chemotherapy with 1-2 cycles of carboplatin dosed at the AUC of 7 did not improve overall survival and due to added toxicity it is not the first option for patients who are willing to undergo surveillance program ${ }^{9,15}$.

\section{Seminoma stage II}

Stage II is defined as a tumor that involves testis and retroperitoneal lymph nodes, without visceral metastases and with normal or raised postorchiectomy serum tumor markers at primary diagnosis. About $15 \%$ to $20 \%$ of patients diagnosed with seminoma are classified as having stage II disease ${ }^{15}$. Postorchiectomy treatment options for stage II seminoma include radiotherapy to para-aortic and ipsilateral iliac lymph nodes to the cumulative dose of 30-36 Gy, multi agent cisplatin based chemotherapy with 3 cycles of cisplatin, etoposide and bleomycin protocol (PEB protocol) or 4 cycles of cisplatin, etoposide protocol (PE protocol). Stage II is divided by AJCC staging system based on the size of involved nodes into stage IIA (nodes $<2$ $\mathrm{cm}$ ), IIB (nodes $2-5 \mathrm{~cm}$ ) and IIC (nodes $>5 \mathrm{~cm}$ ). For stage IIC, there is no debate about the indication for chemotherapy, but for IIA and IIB stages there are some differences among high-volume centers regarding optimal choice of therapy ${ }^{16,17}$.

The National Comprehensive Cancer Network (NCCN) testicular cancer guidelines treatment plan is based on dividing stage II into low volume disease and bulky disease, depending on the maximal size of lymph node mass. In low volume disease, which is defined by involved lymph nodes smaller than $3 \mathrm{~cm}$, radiotherapy is preferred to chemotherapy. In situations where more extensive lymph node involvement is present, chemotherapy is preferable. Bulky disease is defined by involved lymph nodes greater than $3 \mathrm{~cm}$, and in this case chemotherapy is preferred to radiotherapy ${ }^{1,12}$. The European Society for Medical Oncology practice guidelines recommend chemotherapy or radiotherapy for stage IIA, whereas chemotherapy is the preferred option for stages IIB and $\mathrm{IIC}^{18}$. Recent studies predominantly recommend chemotherapy for stage IIA due to the same relapse rates for chemotherapy and radiotherapy. Accordingly, chemotherapy is becoming a more commonly utilized modality for stage IIA as it is for stages IIB and IIC ${ }^{17,19}$.

After completing the initial therapy, patients are evaluated with serum tumor markers and positron emission tomography/computed tomography (PET/ CT) scan. It should be done 6-8 weeks after completion of chemotherapy to reduce the incidence of falsepositive results. Patients with complete response to primary treatment need only surveillance. In cases where residual retroperitoneal mass is metabolically active, greater than $3 \mathrm{~cm}$, with normal levels of tumor markers, there is a higher possibility of residual seminoma. A biopsy of residual mass should be considered before decision on further treatment option. Postchemotherapy retroperitoneal lymph node dissection (PC-RPLND) is difficult to perform in case of pure seminoma due to desmoplastic reaction and adherence to main blood vessels. In cases of biopsy proven residual viable seminoma, salvage treatment (chemotherapy or radiotherapy) is indicated, while surveillance is preferable otherwise. In patients with positive PET/ CT scan and rising tumor markers, the option is salvage chemotherapy ${ }^{12,18}$.

\section{Non-seminoma stage I}

Stage I is defined as a tumor limited to the testis, without retroperitoneal lymph node involvement or visceral metastases and without increased postorchiectomy serum tumor markers at primary diagnosis. About $70 \%$ of patients are diagnosed at this stage. The overall relapse rate is $30 \%$ following orchiectomy. This means that $70 \%$ of patients are cured by orchiectomy alone, and by receiving adjuvant treatment they would be unnecessarily exposed to the potential adverse events ${ }^{20}$. 
The investigated risk factors for predicting disease relapse include the presence of lymphovascular invasion and the predominant subtype of embryonal carcinoma in the orchiectomy histologic specimen. Because of inconclusive data, predominant embryonal carcino$\mathrm{ma}$ as a risk factor is not accepted in routine practice. Based on the absence or presence of lymphovascular invasion, stage I non-seminoma can be divided into low-risk stage IA and high-risk stage IB. The relapse rate is $15 \%-20 \%$ in stage IA and $40 \%-50 \%$ in stage IB without adjuvant treatment ${ }^{2}$.

Following orchiectomy, there are 3 recommended options for the management of stage I non-seminoma, including active surveillance, adjuvant chemotherapy with 1-2 cycles of chemotherapy with PEB protocol, or primary nerve-sparing retroperitoneal lymph node dissection (p-RPLND). Each option has a cure rate of $99 \%{ }^{20}$. At our Referral Center, as in other European high-volume centers, the preferred option for stage IA is active surveillance and for stage IB adjuvant chemotherapy with 1 cycle of $\mathrm{PEB}$ protocol.

Adjuvant chemotherapy is associated with the lowest risk of disease recurrence (1\%-5\%) among the 3 treatment options. The main disadvantage is the toxicity risk, which is related to the number of $\mathrm{PEB}$ protocol cycles. Some findings confirm that applying 1 instead of 2 cycles of adjuvant PEB chemotherapy significantly reduces toxicity without a major increase in the risk of relapse (90\%-95\%) ${ }^{21,22}$. If only 1 cycle of PEB chemotherapy is planned, chest radiography with tumor markers within 1 week and abdominal computed tomography within 4 weeks before treatment are necessary to confirm that the patient is still in stage I. The recommendations concerning treatment options differ among high-volume centers. The preferred option for stage IA is active surveillance, and the alternative options are p-RPLND and chemotherapy. The preferred option for stage IB is chemotherapy, and the alternative options are p-RPLND and active surveillance ${ }^{9}$. Advantages of $\mathrm{p}$-RPLND include reduction in the need for chemotherapy, complete staging of the retroperitoneum, minimized relapse rates in the retroperitoneum, and reduced period of only 1 year of radiological monitoring after negative $\mathrm{p}$-RPLND. The $\mathrm{p}$-RPLND is a therapeutic option in the case of occult stage II, especially if chemoresistant teratoma is found. Some experts even consider p-RPLND as the preferred option for patients with teratoma and somatic transformation in primary tumor ${ }^{18,20}$. Although it is not frequently used today, $\mathrm{p}$-RPLND is an option for patients who refuse chemotherapy treatment and do not want to be in surveillance program, especially if they have a $50 \%$ risk of relapse ${ }^{2,9}$. Active surveillance is rarely offered to patients in stage IB because of higher relapse rates, with good compliance as a critical issue when this treatment modality is commenced. Those who experience relapse during active surveillance program should be treated with chemotherapy ${ }^{9}$.

\section{Non-seminoma stage II}

Stage II is defined as a tumor that involves the testis and retroperitoneal lymph nodes, without visceral metastases and with normal or raised postorchiectomy serum tumor markers at primary diagnosis. It is divided depending on the size of involved lymph nodes in stages IIA (nodes $<2 \mathrm{~cm}$ ), IIB (nodes $2-5 \mathrm{~cm}$ ) and IIC (nodes $>5 \mathrm{~cm})^{12}$. For stage IIC, there is a universal consensus about the indication for postorchiectomy chemotherapy with 3 cycles of $\mathrm{PEB}$ protocol or $4 \mathrm{cy}-$ cles of $\mathrm{PE}$ protocol. On the contrary, there are some differences among high-volume centers concerning optimal choice of therapy for stages IIA and IIB, which depends on the level of postorchiectomy tumor markers ${ }^{1}$. For stage IIA with negative tumor markers, the European and NCCN guidelines recommend close follow up of the suspected lymph node involvement. In case of volume progression, treatment options can be p-RPLND or chemotherapy with 3 cycles of $\mathrm{PEB}$ protocol or 4 cycles of $\mathrm{PE}$ protocol. In case of positive tumor markers, treatment options are the above-mentioned chemotherapeutic protocols. For stage IIB with negative tumor markers and surgically manageable lymph node involvement, the treatment option in highly selected cases can be p-RPLND. In all other cases, the treatment option is chemotherapy, as mentioned above ${ }^{12,18}$.

After primary treatment with p-RPLND, adjuvant chemotherapeutic treatment should be considered depending on the number and size of positive lymph nodes. After primary treatment with chemotherapy, patients are evaluated by serum tumor markers and radiological imaging. If complete remission is achieved, which means negative tumor markers and retroperitoneal lymph nodes smaller than $1 \mathrm{~cm}$, no further treatment is needed. In case of negative tumor markers and residual lymph nodes greater than $1 \mathrm{~cm}$, bilateral PC- 
RPLND should be performed ${ }^{1,2}$. PC-RPLND is diagnostically important to differentiate the type of tumor mass, and in case of teratoma it is the therapeutic option since teratoma is chemo- and radio-resistant. In PC-RPLND histology specimens, necrosis can be found in $40 \%-50 \%$, teratoma in $35 \%-40 \%$ and viable germ cell carcinoma in $10 \%-15 \%$ of cases ${ }^{23}$. Only in case of viable germ cell carcinoma, further adjuvant treatment with 2 cycles of conventional chemotherapy should be considered ${ }^{12}$. Some studies have shown the existence of residual teratoma in subcentimeter retroperitoneal nodes following chemotherapy, but PCRPLND on such lymph nodes did not improve the overall outcome ${ }^{24}$.

\section{Seminoma and non-seminoma stage III}

Stage III is defined as a tumor that has spread to distant lymph nodes or to any other organ. After the new risk stratification model was published by the International Germ Cell Cancer Collaborative Group (IGCCCG) in 1997, treatment guideline has been tailored accordingly. The model classifies patients with advanced disease into good, intermediate and poor prognosis groups based on the level of tumor markers and the location of primary and metastatic germ cell tumor ${ }^{1}$.

\section{Primary treatment of good-risk disease}

About $60 \%$ of all metastatic cases are classified as good-risk disease, with 5-year overall survival rate of 91\%. Seminoma stages IIIA and IIIB and non-seminoma stage IIIA fall into that category. Following orchiectomy, the preferred regimen for good-risk patients is 3 cycles of $\mathrm{PEB}$ protocol, which showed the same cure benefit as 4 cycles, but with significant reduction of toxicity ${ }^{13}$. For patients who cannot receive bleomycin, treatment option is 4 cycles of $\mathrm{PE}$ protocol. Although some trials showed advantages of treatment with 3 cycles of PEB protocol over 4 cycles of PE protocol, the results were not statistically significant. The cure rate with chemotherapy is about $90 \% \%^{11,13}$.

\section{Primary treatment of intermediate/poor-risk disease}

About $26 \%$ of all metastatic cases are classified as intermediate-risk disease with 5-year overall survival rate of $79 \%$, and about $14 \%$ of metastatic cases are classified as poor-risk with 5-year overall survival rate of $48 \%$. Seminoma stage IIIC and non-seminoma stage IIIB fall into intermediate risk, and non-seminoma stage IIIC falls into poor risk category.

The preferred postorchiectomy regimen for those patients is 4 cycles of $\mathrm{PEB}$ protocol. In patients for whom bleomycin is not acceptable, treatment option is 4 cycles of cisplatin, ifosfamide and etoposide (PEI protocol). There was no statistically significant difference in the outcome compared to 4 cycles of PEB protocol, but it caused greater myelotoxicity and genitourinary toxicity. Granulocyte colony-stimulating factor support is recommended whenever PEI protocols are chosen. A combination of cisplatin, ifosfamide and paclitaxel (TIP protocol) has also shown promising efficacy as first-line therapy in intermediate/poor risk patients. There is an ongoing phase 2 trial comparing PEB and TIP protocols in those patients (NCT01873326) ${ }^{11,13}$. The cure rate for intermediate risk patients treated by chemotherapy is about $80 \%$ and for poor-risk patients $50 \%-60 \%{ }^{1}$. High-dose chemotherapy (HDCT) followed by autologous stem cell transplantation (ASCT) as the first-line therapy in intermediate/poor-risk patients did not show survival advantage over standard treatment with PEB or PEI protocol, and thus it is not recommended in routine use. Some investigators think it should be considered in selected poor-risk patients with unsatisfactory tumor marker decline after first or second cycle of PEB chemotherapy, those with initial brain metastases and patients with mediastinal primary tumor ${ }^{1,13}$. After primary treatment with chemotherapy, patients with non-seminoma are evaluated with serum tumor markers and computed tomography imaging. If complete remission is achieved, no further treatment is needed. In case of negative tumor markers and residual disease, all sites of residual retroperitoneal and extraperitoneal disease should be surgically removed. Unlike lung, liver and neck disease, the role of surgery in patients with brain metastasis is less common because of the efficacy of new radiation techniques combined ${ }^{25}$. Patients with stage III seminoma are evaluated with tumor markers and PET/CT scan 6-8 weeks after primary treatment with chemotherapy. Depending on the results, further procedure is similar as in stage II seminoma ${ }^{1,2}$.

\section{Stage IS seminoma and non-seminoma}

Stage IS is defined as raised postorchiectomy markers without radiological evidence of disease. Before 
starting the treatment, other causes of raised tumor markers must be excluded. Elevated levels of bHCG can be seen in marijuana users and in patients with mononucleosis, or because of cross reactivity with luteinizing hormone, while increased AFP can be a sign of liver disease ${ }^{26}$. Sustained rise in tumor marker levels is an indication for salvage chemotherapy with the exception of isolated high $\mathrm{LDH}$, as it can be elevated in various medical conditions. Stage IS falls into goodrisk category and patients with non-seminoma are treated with 3 cycles of $\mathrm{PEB}$ protocol or 4 cycles of $\mathrm{PE}$ protocol. The preferred treatment is chemotherapy because of the high probability of disease dissemination. Stage IS seminoma is a rare condition and patients are treated with primary radiotherapy ${ }^{12}$.

\section{Salvage Treatment of Relapsed and Progressive Germ Cell Tumors}

Up to $30 \%$ of patients will have relapse or progressive disease after first-line cisplatin based chemotherapy, which is diagnosed during post-treatment followup as an increase in tumor marker levels or/and radiographic progression ${ }^{11}$. In case of isolated tumor marker increase and absence of radiographic progression, relapse in brain or second primary in the contralateral testis must be excluded. Other causes of raised tumor markers should also be ruled out ${ }^{26}$.

The choice of first salvage treatment/second-line therapy is still a matter of debate. There are two salvage approaches, conventional-dose chemotherapy (CDCT) and HDCT followed by ASCT. Determining when to treat with CDCT or with HDCT has been investigated throughout the last three decades with predominantly retrospective analyses, which showed possible benefit from HDCT compared to CDCT. The only prospective trial that compared $\mathrm{CDCT}$ and $\mathrm{HDCT}$ in first salvage treatment failed to prove any significant difference ${ }^{13,27,28}$. The NCCN guidelines recommend CDCT for patients with favorable prognostic factors (low volume of disease, low tumor markers, complete response to first-line chemotherapy) and high-dose programs for patients with unfavorable prognostic factors $^{12}$. The International Prognostic Factor Study Group categorizes relapsed patients into five prognostic groups, from very low-risk to very high-risk group. Accordingly, some investigators propose the use of HDCT followed by ASCT only in high-risk groups, whereas others propose it in all groups except for the very low-risk group ${ }^{1,13}$. Currently, a prospective randomized phase 3 trial (TIGER) is comparing CDCT with HDCT. The results should provide answer about the most efficient first salvage approach and elucidate which risk group requires HDCT followed by ASCT as first salvage treatment ${ }^{11,13}$.

Three chemotherapy options in CDCT include the TIP protocol, the combination of cisplatin, ifosfamide and vinblastine (VeIP protocol) and PEI protocol in a rare subgroup of patients who did not receive etoposide as part of first-line therapy ${ }^{26,29}$. There are no headto-head studies comparing these three protocols, but TIP protocol has become the preferred regimen owing to better results of durable complete response as compared to VeIP protocol ${ }^{11}$. The GETUG phase II trial incorporated gemcitabine in cisplatin and ifosfamide combination for the first time. The so-called GIP protocol showed efficacy as first salvage therapy, especially in patients with preexisting neuropathy ${ }^{13,29}$.

A second salvage option/third-line therapy is HDCT, including high doses of carboplatin and etoposide. First choice of HDCT regimen is the protocol which consists of 2 cycles of citoreductive therapy and stem cell mobilization with paclitaxel and ifosfamide, followed by 3 cycles of high dose chemotherapy with carboplatin and etoposide (CE) with stem cell transplantation. Another choice is citoreductive therapy and stem cell mobilization with PEI protocol, followed by 2 cycles of high dose $\mathrm{CE}$ regimen and supported with stem cell transplantation ${ }^{13,26,29}$. After first salvage treatment, secondary resections of non-seminoma residual masses greater than $1 \mathrm{~cm}$ are mandatory to improve treatment outcome ${ }^{13}$.

Relapses after the first salvage treatment are very challenging to treat due to cisplatin resistance. Therapy options for second salvage treatment/third-line therapy are combinations of gemcitabine and oxaliplatin, gemcitabine and oxaliplatin together with paclitaxel and gemcitabine with paclitaxel for patients who did not receive prior paclitaxel therapies ${ }^{13,26}$. Salvage surgery is sometimes needed in combination with chemotherapy if there is a single site of residual disease. Depending on patient performance status and comorbidities, some investigators offer HDCT with ASCT as second salvage therapy ${ }^{29}$. Late relapse is defined as a disease relapse two years after finishing the initial chemotherapeutic treatment. Management is very chal- 
lenging due to more aggressive histology and development of chemoresistant clones encouraged with previous chemotherapeutic treatment. It is a distinct clinical entity and occurs in about $2 \%-3 \%$ of survivors ${ }^{30}$. Non-seminomas are difficult to cure with only salvage chemotherapy because of higher rates of teratoma existing in relapsed masses, sometimes with somatic malignant differentiation. This fact makes a combination of chemotherapy and surgical resection the preferred option of treatment, if it is technically feasible. Seminomas should be treated with chemotherapy alone. More than $30 \%$ of late relapses may occur more than 10 years after the primary treatment and there is a question of lifelong follow-up in patients with GCTC $^{31}$.

All the above mentioned was about patients who experience relapse after achieving complete response to primary treatment with cisplatin based chemotherapy. Relapsed patients whose primary treatment did not include cisplatin based chemotherapy, but were managed with postorchiectomy active surveillance, adjuvant treatment with radiotherapy or p-RPLND, should be treated per risk status published by the IGCCCG group ${ }^{12}$.

\section{Special Considerations in Treatment Plan}

\section{Somatic type malignancy}

It is known that $2.7 \%-8.6 \%$ of non-seminomas have non-germ cell components. The most common ones are sarcomas, primitive neuroectodermal tumors (PNET), carcinomas and hematologic malignancies. Those somatic-type malignancies are transformed from pluripotent teratoma cells and are in most cases chemoresistant. The prognosis of such tumors is very poor despite aggressive surgical resection combined with chemotherapy. Cisplatin based chemotherapy is directed to the germ-cell histology subgroup and repeated surgical treatment is directed to somatic component. Treatment in high-volume centers with multidisciplinary approach is crucial ${ }^{32}$. In case of PNETs there are some attempts to improve treatment with surgical resections combined with chemotherapy in the adjuvant and metastatic setting. The used combination is cyclophosphamide, doxorubicin and vinblastine alternating it with ifosfamide and etoposide, as it is thought that peripheral PNETs are part of Ewing sarcoma family ${ }^{33}$.

\section{Choriocarcinoma}

Up to $8 \%$ of non-seminomas contain a choriocarcinoma component, and $0.2 \%-0.6 \%$ are pure choriocarcinomas. Choriocarcinomas arise from extraembryonal differentiation and because of trophoblastic phenotype they secrete high levels of $\mathrm{bHCG}^{7}$. Because of rapid hematogenous spread to multiple organs (brain, lungs, liver, etc.) with intratumoral bleeding that can be rapidly fatal, those patients should be treated in high-volume centers and treatment strategy must be individualized for every patient. In cases of high-volume disease, chemotherapy should not be delayed because of orchiectomy or sperm banking. Immediate chemotherapy improves survival. In cases of lung metastases, bleomycin should not be given in the first cycle because of potential respiratory failure and first cycle with PE protocol should be shortened in unstable patient to avoid complications of rapid tumor lysis syndrome ${ }^{34}$.

\section{Conclusion}

After the introduction of cisplatin based chemotherapeutic protocols alongside advances in postchemotherapy surgical techniques and radiation, testicular cancer has become a model of curable cancer. The general success of treatment is always a result of collaboration within a multidisciplinary team. With a myriad of therapeutic options appearing on the horizon, it is of utmost importance to thoroughly present all the advantages and disadvantages of a particular option to the patient. Adhering to that premise, we can achieve maximal objective response and offer the opportunity of longstanding high quality of life.

\section{References}

1. Adra N, Einhorn LH. Testicular cancer update. Clin Adv Hematol Oncol. 2017;15:386-96. PubMed PMID: 28591093.

2. Ehrlich Y, Margel D, Lubin MA, Baniel J. Advances in the treatment of testicular cancer. Transl Androl Urol. 2015;4: 381-90. PubMed PMID: 26816836. doi: 10.3978/j.issn.22234683.2015.06.02.

3. Croatian Institute of Public Health, Croatian National Cancer Registry. Cancer Incidence in Croatia 2014. Bulletin No. 39. Zagreb; 2016.

4. Sincic N, Kulis T, Znaor A, Bray F. Time trends in testicular cancer in Croatia 1983-2007: rapid increases in incidence, no 
declines in mortality. Cancer Epidemiol. 2012;36:11-5. Epub 2011 Oct 20. PubMed PMID: 22014475. doi: 10.1016/j. canep.2011.09.010.

5. Le Cornet C, Lortet-Tieulent J, Forman D, Béranger R, Flechon A, Fervers B, et al. Testicular cancer incidence to rise by $25 \%$ by 2025 in Europe? Model-based predictions in 40 countries using population-based registry data. Eur J Cancer. 2014;50:831-9. Epub 2013 Dec 23. PubMed PMID: 24369860. doi: 10.1016/j.ejca.2013.11.035.

6. Sharma P, Dhillon J, Sexton WJ. Intratubular germ cell neoplasia of the testis, bilateral testicular cancer and aberrant histologies. Urol Clin North Am. 2015;42:277-85. Epub 2015 Jun 6. PubMed PMID: 26216815. doi: 10.1016/j.ucl.2015.04.002.

7. Hanna NH, Einhorn LH. Testicular cancer - discoveries and updates. N Engl J Med. 2014;371:2005-16. PubMed PMID: 25409373. doi: 10.1056/NEJMra1407550.

8. Rajpert-De Meyts E. Developmental model for the pathogenesis of testicular carcinoma in situ: genetic and environmental aspects. Hum Reprod Update. 2006;12:303-23. Epub 2006 Mar 15. PubMed PMID: 16540528. doi: 10.1093/humupd/ dmk006.

9. Chovanec M, Hanna N, Cary KC, Einhorn L, Albany C. Management of stage I testicular germ cell tumours. Nat Rev Urol. 2016;13:663-73. Epub 2016 Sep 13. PubMed PMID: 2761 8772. doi: 10.1038/nrurol.2016.164.

10. American Cancer Society. Cancer Facts \& Figures 2017. Atlanta; 2017. Available from: https://cancerstatisticscenter. cancer.org/?_ga=2.170978467.262523554. 1523954380-7643 2436.1523954380\#!/cancer-site/Testis

11. Funt SA, Feldman DR, Bosl GJ. The management of advanced germ cell tumors in 2016: The Memorial Sloan Kettering Approach. Oncology (Williston Park). 2016;30:653-64. PubMed PMID: 27422113.

12. National Comprehensive Cancer Network v 1.2018. Clinical Practice Guidelines in Oncology, Testicular Cancer [cited 2018 Feb 15]. Available from: http://www.ncen.org

13. Oing C, Seidel C, von Amsberg G, Oechsle K, Bokemeyer C. Pharmacotherapeutic treatment of germ cell tumors: standard of care and recent developments. Expert Opin Pharmacother. 2016;17:545-60. Epub 2015 Dec 31. PubMed PMID: 26630452. doi: 10.1517/14656566.2016.1127357.

14. Loriot Y, Fizazi K. Management of clinical stage I testicular germ cell tumours. Bull Cancer. 2007;94:439-48. PubMed PMID: 17535781.

15. Pearce SM, Liauw SL, Eggener SE. Management of low-stage testicular seminoma. Urol Clin North Am. 2015;42:287-98. Epub 2015 Jun 6. PubMed PMID: 26216816. doi: 10.1016/j. ucl.2015.04.003.

16. Tandstad T, Smaaland R, Solberg A, Bremnes RM, Langberg CW, Laurell A, et al. Management of seminomatous testicular cancer: a binational prospective population-based study from the Swedish Norwegian testicular cancer study group. J Clin Oncol. 2011;29:719-25. Epub 2011 Jan 4. PubMed PMID: 21205748. doi: 10.1200/JCO.2010.30.1044.
17. Giannatempo P, Greco T, Mariani L, Nicolai N, Tana S, Farè E, et al. Radiotherapy or chemotherapy for clinical stage IIA and IIB seminoma: a systematic review and meta-analysis of patient outcomes. Ann Oncol. 2015;26:657-68. Epub 2014 Sep 11. PubMed PMID: 25214543. doi: 10.1093/annonc/mdu447.

18. Oldenburg J, Fosså SD, Nuver J, Heidenreich A, Schmoll H-J, Bokemeyer C, et al. ESMO Guidelines Working Group, Testicular seminoma and non-seminoma: ESMO Clinical Practice Guidelines for diagnosis, treatment and follow-up. Ann Oncol. 2013;24 Suppl 6:vi125-32. PubMed PMID: 24078656. doi: 10.1093/annonc/mdt304.

19. Paly JJ, Lin CC, Gray PJ, Hallemeier CL, Beard C, Sineshaw $\mathrm{H}$, et al. Management and outcomes of clinical stage IIA/B seminoma: results from the National Cancer Data Base 19982012. Pract Radiat Oncol. 2016;6:e249-e58. Epub 2016 May 8. PubMed PMID: 27345128. doi: 10.1016/j.pro.2016.05.002. Epub 2016 May 8.

20. Kovac E, Stephenson AJ. Management of stage I nonseminomatous germ cell tumors. Urol Clin North Am. 2015;42: 299-310. PubMed PMID: 26216817. doi: 10.1016/j.ucl. 2015.04.004.

21. Tandstad T, Ståhl O, Håkansson U, et al. One course of adjuvant BEP in clinical stage I nonseminoma mature and expanded results from the SWENOTECA group. Ann Oncol. 2014; 25:2167-72. Epub 2014 Aug 11. PubMed PMID: 25114021. doi: 10.1093/annonc/mdu375.

22. Tandstad T, Dahl O, Cohn-Cedermark G, et al. Risk-adapted treatment in clinical stage I nonseminomatous germ cell testicular cancer: the SWENOTECA management program. J Clin Oncol. 2009;27:2122-8. Epub 2009 Mar 23. PubMed PMID: 19307506. doi: 10.1200/JCO.2008.18.8953.

23. Chéry L, Dash A. The role of postchemotherapy surgery in germ cell tumors. Urol Clin North Am. 2015;42:331-42. Epub 2015 Jun 19. PubMed PMID: 26216820. doi: 10.1016/j. ucl.2015.04.007.

24. Einhorn LH, Foster RS. What are the indications for postchemotherapy retroperitoneal lymph node dissection? Ann Oncol. 2014;25:301-3. Epub 2014 Jan 3. PubMed PMID: 24389117. doi: 10.1093/annonc/mdt493.

25. Hu B, Daneshmand S. Role of extraretroperitoneal surgery in patients with metastatic germ cell tumors. Urol Clin North Am. 2015;42:369-80. Epub 2015 Jun 16. PubMed PMID: 26216824. doi: 10.1016/j.ucl.2015.04.011.

26. Rashdan S, Einhorn LH. Salvage therapy for patients with germ cell tumor. J Oncol Pract. 2016;12:437-43. PubMed PMID: 27170693. doi: 10.1200/JOP.2016.011411.

27. Lorch A, Bascoul-Mollevi C, Kramar A, Einhorn L, Necchi A, Massard C, et al. Conventional-dose versus high-dose chemotherapy as first salvage treatment in male patients with metastatic germ cell tumors: evidence from a large international database. J Clin Oncol. 2011;29:2178-84. Epub 2011 Mar 28. PubMed PMID: 21444870. doi: 10.1200/JCO.2010.32.6678.

28. Pico JL, Rosti G, Kramar A, Wandt H, Koza V, Salvioni R, et al. A randomised trial of high-dose chemotherapy in the sal- 
vage treatment of patients failing first-line platinum chemotherapy for advanced germ cell tumours. Ann Oncol. 2005; 16:1152-9. Epub 2005 May 31. PubMed PMID: 15928070. doi: 10.1093/annonc/mdi228.

29. Allen JC, Kirschner A, Scarpato KR, Morgans AK. Current management of refractory germ cell tumors and future directions. Curr Oncol Rep. 2017;19:8. PubMed PMID: 28220447. doi: 10.1007/s11912-017-0572-y.

30. O'Shaughnessy MJ, Feldman DR, Carver BS, Sheinfeld J. Late relapse of testicular germ cell tumors. Urol Clin North Am. 2015;42:359-68. Epub 2015 Jun 16. PubMed PMID: 262 16823. doi: 10.1016/j.ucl.2015.04.010.

31. Rice KR, Beck SD, Pedrosa JA, Masterson TA, Einhorn LH, Foster RS. Surgical management of late relapse on surveillance in patients presenting with clinical stage I testicular cancer. Urology. 2014;84:886-90. PubMed PMID: 25260450. doi: 10.1016/j.urology.2014.05.054.
32. Rice KR, Magers MJ, Beck SD, Cary KC, Einhorn LH, U1bright TM, et al. Management of germ cell tumors with somatic type malignancy: pathological features, prognostic factors and survival outcomes. J Urol. 2014;192:1403-9. Epub 2014 Jun 18. PubMed PMID: 24952240. doi: 10.1016/j. juro.2014.05.118.

33. Al-Hader AA, Jain A, Al-Nasrallah N, Einhorn LH. Metastatic malignant transformation of teratoma to primitive neuroectodermal tumor (PNET): results with PNET-based chemotherapy. Am J Clin Oncol. 2015;38:364-6. PubMed PMID: 23799289. doi: 10.1097/COC.0b013e31829d1ed7.

34. Reilley MJ, Pagliaro LC. Testicular choriocarcinoma: a rare variant that requires a unique treatment approach. Curr Oncol Rep. 2015;17:2. PubMed PMID: 25645112. doi: 10.1007/ s11912-014-0430-0.

Sažetak

\section{LIJEČENJE GERMINATIVNOG RAKA TESTISA}

\section{A. Koši Kunac, M. Gnjidić, Z. Antunac Golubić i M. Gamulin}

Germinativni rak testisa je maligna novotvorina podrijetla primordijalne zametne stanice. Iako čini oko $1 \%$ svih malignih novotvorina muškaraca, najčešći je malignom mlađe muške populacije s najvećom incidencijom u dobi od 15 do 35 godina. Incidencija raka testisa povećala se globalno posljednjih nekoliko desetljeća, s prosječnim porastom u incidenciji od 7\% godišnje u Hrvatskoj u razdoblju od 1983. do 2007. godine. S obzirom na histološku sliku, germinativni rak testisa dijeli se na seminome i neseminome koji se razlikuju u načinu liječenja i odgovoru na terapiju. Unatoč porastu u incidenciji, obećavajuća okolnost je da je rak testisa postao model izlječivog tumora. Zbog napretka u dijagnostičkim postupcima, sofisticiranih tehnika zračenja, a osobito uvođenja kemoterapijskih protokola baziranih na platini zajedno s naprednim postkemoterapijskim kirurškim tehnikama, izlječivost se očekuje u oko $95 \%$ svih dijagnosticiranih bolesnika s rakom testisa i oko $70 \%$ bolesnika s uznapredovalom bolešću. U ovom preglednom radu usredotočit ćemo se na strategije liječenja germinativnog raka testisa.

Ključne riječi: Germinativni rak testisa; Seminom; Neseminom; Liječenje 